\title{
Halina ŚWIĘCZKOWSKA
}

\author{
"W POSZUKIWANIU TRADYCJI" \\ LEIBNIZJAŃSKI PROJEKT JĘZYKA UNIWERSALNEGO
}

Leibniz jako językoznawca, podobnie zresztą jak wielu innych filozofów, którym nieobca była refleksja językowa, jest wciąż jeszcze $\mathrm{w}$ historii lingwistyki postacią rozpoznaną jedynie częściowo. Niekiedy można odnieść wrażenie, że wkład tego filozofa w badania nad językiem jest albo ignorowany albo traktowany lekceważąco czy nieżyczliwie ${ }^{1}$. Zadziwiające jest choćby całkowite milczenie o teorii lingwistycznej Leibniza w pracach Chomsky'ego ${ }^{2}$, choć $\mathrm{z}$ całą pewnością słuszniejsze byłoby określenie lingwistyki kartezjańskiej mianem leibnizjańskiej. W literaturze światowej od kilkudziesięciu lat można zaobserwować wzmożone zainteresowanie dorobkiem lingwistycznym XVII i XVIII stulecia. Literatura polska dotycząca tego okresu historii językoznawstwa przedstawia się dość skromnie, a wiedza o Leibnizu jako teoretyku i filozofie języka jest udziałem niewielkiego kręgu wtajemniczonych. Należy doń niewątpliwie profesor Anna Wierzbicka, która w połowie lat siedemdziesiątych podjęła próbę poszukiwania tradycji współczesnej semantyki, analizując jej leibnizjańskie korzenie ${ }^{3}$.

Gottfried Wilhelm Leibniz, twórca jednego z największych nowożytnych systemów filozoficznych zasługuje na uwagę jako teoretyk języka z kilku co najmniej powodów. Po pierwsze ze względu na podjęcie przezeń kwestii poznawczej funkcji znaku językowego i jego roli

1 Zob. P. Guiraud, La Sémantique, wyd. 7. Paris 1972, 100.

2 Zob. N. Chomsky, Cartesian Linguistics, New York 1966. Bardzo interesujące rozważania na temat przyczyn nieobecności Leibniza w „lingwistyce kartezjańskiej” prowadzi Hans Arsleff m.in. $\mathrm{w}$ rozprawie p.t. The History of Linquistics and Professor Chomsky, w: H. Aarsleff, From Locke to Saussure, Athlone, London 1982.

3 A. Wierzbicka, W poszukiwaniu tradycji. Idee semantyczne Leibniza, "Pamiętnik Literacki” LXVI, 1975, z 1, s. 108-126. 
w procesie myślowym. Leibnizjańska teoria poznania zbudowana jest w znacznej mierze na językowym fundamencie ${ }^{4}$. Po drugie jest Leibniz przedstawicielem nurtu językoznawstwa materiałowego, autorem wielu studiów i rozpraw, w których podejmuje problematykę pochodzenia języka i klasyfikacji genealogicznej języków świata, prowadzi także badania na temat funkcji języka w życiu jednostki i społeczeństwa, podkreślając jego kulturotwórczy charakter ${ }^{5}$. Po trzecie wreszcie jest Leibniz rozpoznawany najczęściej jako jeden $\mathrm{z}$ pomysłodawców idei języka uniwersalnego, idei która towarzyszyła mu od początku jego drogi naukowej. Idea ta pozostawała niewątpliwie $\mathrm{w}$ ścisłym związku z budowanym przezeń systemem filozoficznym. Można przypuszczać, że kolejne projekty Leibniza zmierzające do jej urzeczywistnienia wynikały również $\mathrm{z}$ intensywnych badań nad istniejącymi już systemami językowymi $w$ bardzo szerokim ich rozumieniu. Paradoksalnie jednak, choć identyfikowany $z$ ideą języka doskonałego, Leibniz nie wyszedł nigdy poza wstępne szkice i komentarze dotyczące tego projektu. Warto zatem prześledzić racje uzasadniające potrzebę utworzenia takiego języka i cele, które za jego pomocą chciał osiągnąć. Esej ten jest próbą udzielenia przynajmniej częściowej odpowiedzi na pytanie o motywację Leibniza na rzecz potrzeby języka uniwersalnego. Jest ono zasadne między innymi ze względu na stojącą $\mathrm{w}$ sprzeczności $\mathrm{z}$ ideą języka uniwersalnego jedną $\mathrm{z}$ wypowiedzi Leibniza, w której wyraźnie podkreśla on, że „każdy język, nawet najuboższy, może wyrażać wszystko" 6 , jak również z uwagi na historyczny wkład Leibniza $\mathrm{w}$ ideę formalizacji i mechanizacji procesów rozumowań7. Jest to również próba rekonstrukcji paradygmatu badań językowych obowiązującego $\mathrm{w}$ pewnym obszarze siedemnastowiecznej teorii języka.

4 G. W. Leibniz, Unvorgreiffliche Gedancken, w: G. W. Leibniz, Collectanea Etymologica..., Hanoverae 1717, § 1, s. 104 (dalej zastąpione skrótem UG). Zob. H. Święczkowska, Harmonia linguarum. Język $i$ jego funkcjie $w$ filozofii Leibniza, Białystok 1998, s. 58-78.

5 Zob. H. Święczkowska, Harmonia linguarum..., wyd. cyt. s. 39-57 oraz s. 80-96 i cytowana tam literatura.

6 G. W. Leibniz, Analysis linguarum, C, s. 352.

7 Zob. W Marciszewski, R. Murawski, Mechanization of Reasoning in a Historical Perspective, Rodopi, Amsterdam - Atlanta 1995, s. 103-112. 


\section{Co wcześniej: uniwersalny język czy prawdziwa filozofia?}

W liście do Mersenne'a z 20 listopada $1629^{8}$ roku Kartezjusz sformułował uwagi na temat projektu języka uniwersalnego, autorstwa niejakiego Hardy'ego, który w rozpowszechnianej w Paryżu ulotce wyłożył w sześciu postulatach swoje poglądy na strukturę takiego języka i zadania, jakie miałby spełniać. Kartezjusz nie był zachwycony projektem. Jego uwagi były tyleż krytyczne, co lekceważące przedsięwzięcie. Postulowany język miał być $w$ intencji projektodawcy językiem quasi-naturalnym $\mathrm{z}$ uproszczoną regularną gramatyką i słownikiem, w którym każde słowo byłoby prawdziwą definicją rzeczy. Język ten, łatwy do opanowania, byłby punktem odniesienia dla innych języków w tym sensie, że istniejące języki etniczne byłyby jego dialektami. Służyłby też, o wiele skuteczniej niż to czynią inne języki, przekazywaniu myśli w mowie i w piśmie 9 .

Krytyczna w dużej mierze recenzja Kartezjusza zawierała także część pozytywną, w której autor dopuszczał możliwość skonstruowania języka uniwersalnego, choć na innej niż u Hardy'ego zasadzie. Zdaniem Kartezjusza błąd Hardy'ego polegał na przeświadczeniu, że skuteczną metodą upraszczania języka $\mathrm{w}$ celu łatwiejszego opanowania go jest eliminowanie tych elementów, które nie są konieczne dla jego funkcjonowania. Ale ilość elementów struktury językowej nie jest sama przez się przyczyną trudności w opanowaniu danego języka. Nawet bardzo bogaty ilościowo system daje się opanować, jeśli jego elementy są uporządkowane według jakiejś przejrzystej zasady. Kartezjusz wyjaśnia, że "Chodzi przecież o to, by można było nauczyć się go w bardzo krótkim czasie, a to jest możliwe dzięki porządkowi, to znaczy dzięki ustaleniu porządku między wszystkimi myślami, jakie może pomieścić umysł ludzki, takiego samego jak ten, który w sposób naturalny ustalony jest między liczbami. I tak w jeden dzień można się nauczyć nazywać wszystkie liczby aż do nieskończoności i pisać je w obcym dla siebie języku, a przecież mamy tu do czynienia z nieskończenie wielką ilością

\footnotetext{
8 R. Descartes, Oeuvres de Descartes. Publiées par Ch. Adam., P. Tannery, Paris 1974-1983, t. I, s. 76-82 (dalej: AT).

9 Zob. J. Kopania, Funkcje poznawcze Descartesa teorii idei, Białystok 1988, s. 191 i n.
} 
różnych słów, tak też można by uczynić z wszelkimi innymi słowami niezbędnymi do wyrażania wszystkiego tego, co napływa do ludzkiego umysłu" 10 .

Istotne zatem - zdaniem Kartezjusza - staje się ustalenie samej zasady konstruowania języka uniwersalnego. Ale to ustalenie zależy „od prawdziwej filozofii; bez niej nie jest bowiem możliwe wyliczyć i uporządkować wszystkie myśli ludzkie, a nawet je tylko rozróżnić tak, by stały się jasne i proste, co moim zdaniem jest największą tajemnicą, którą trzeba odkryć, by zdobyć rzetelną wiedzę. I gdyby ktoś poprawnie wyjaśnił, jakie są zawarte $\mathrm{w}$ wyobraźni ludzi proste idee, z których składa się wszystko, co ludzie myślą, gdyby ponadto wyjaśnienie to zostało powszechnie uznane, wówczas miałbym nadzieję, że zostanie utworzony uniwersalny język, bardzo łatwy do opanowania zarówno w mowie i piśmie, a co najważniejsze taki, który mógłby wspomagać nasz osąd (jugement), przedstawiając mu wszystko tak wyraźnie, że prawie niemożliwym byłoby mylić się" 11 .

Leibniz, dysponując kopią tego listu, skomentował wypowiedź Kartezjusza następująco: „Choć język ten zależy od prawdziwej filozofii, nie zależy wcale od jej doskonałości. Można go bowiem ustanowić nawet, jeśli filozofia nie jest jeszcze doskonała, podobnie jak niedoskonała jest nasza wiedza. Tymczasem byłby on nadzwyczaj pomocny w przechowywaniu tego, co wiemy, przeglądaniu naszych niedostatków, odkrywaniu sposobów ich osiągnięcia, a przede wszystkim w rozstrzyganiu wątpliwości, gdy w grę wchodzi poprawność łańcucha rozumowań" 12

10 AT I, 80-81, przekład: J. Kopania, op. cit., s. 199.

11 AT I, 81, przekład: J. Kopania, op. cit., s. 200.

12 G. W. Leibniz, Opuscules et Fragments Inédits de Leibniz, extraits des manuscrits de la bibliothèque royale de Hanovre par Louis Couturat, Paris 1903 (repr. Hildesheim 1963), s. 28 (dalej: C): "Cependant quoyque cette langue depende de la vraye philosophie, elle ne depend pas de sa perfection. C'est à dire cette langue peut estre établie, quoyque la philosophie ne soit pas parfaite: et à mesure que la science des hommes croistra, cette langue. En attendant elle sera d'un secours merveilleux et pour se servir de ce que nous scavons, et pour vior ce qui nous manque, et pour inventer les moyens d'y arriver, mais sur tout pour extreminer les controverses dans les matieres qui dependent du raisonnement. Car alors raisonner et calculer sera la même chose". 


\subsection{De arte combinatoria}

Nie wiadomo, czy Leibniz znał cytowany wyżej list Kartezjusza, gdy pisał jedną z najważniejszych młodzieńczych prac Dissertatio de arte combinatoria. Ale logiczne i matematyczne wyniki tej rozprawy stworzyły podstawę jego dalszych filozoficznych przedsięwzięć. W De arte combinatoria Leibniz, nawiązując do prac nowożytnych matematyków i filozofów, a także do metody opisywanej w pismach średniowiecznego katalońskiego encyklopedysty Rajmunda Lullusa, rozwija ideę utworzenia alfabetu ludzkiej myśli. Leibniz wierzył, że wszystkie pojęcia są jedynie kombinacjami prostych, podstawowych pojęć, podobnie jak słowa są nieskończenie zróżnicowanymi kombinacjami liter alfabetu. Ideę tę wyraził następująco: „Rozłóżmy jakikolwiek dany termin na jego składniki formalne, tj. zdefiniujmy go. Następnie rozłóżmy te składniki na ich własne części, czyli dajmy definicje terminów (pierwszej definicji), póki nie dotrzemy do prostych części czy niedefiniowalnych terminów" ${ }^{13}$. Te proste niedefiniowalne części tworzyłyby alfabet ludzkiej myśli. Poprzez ich zestawienie można więc odkryć wszystkie prawdy, które te połączenia wyrażają.

Punktem wyjścia dla tej idei był $\mathrm{w}$ istocie tradycyjny system definicji przez rodzaj bliższy (genus proximum) i różnicę gatunkową (differentia specifica). Zgodnie $\mathrm{z}$ tym podejściem, wywodzącym się od Platona i Arystotelesa, właściwą metodą definiowania klas rzeczy jest rozpoczęcie od klasy najbardziej ogólnej i podział jej na dwie mniejsze wzajemnie wykluczające się klasy. Skuteczność tej metody wzmacniało przekonanie, że pojęcie definiowane musi być bardziej złożone niż pojęcia użyte $\mathrm{w}$ definiensie. Zatem, jeżeli pojęcie 'człowiek' jest połączeniem pojęć 'zwierzę' i 'rozumny', to składniki te powinny być prostsze niż złożone $\mathrm{z}$ nich pojęcie. Pociągało to za sobą przypuszczenie o istnieniu absolutnie prostych, atomowych pojęć - gdyż w przeciwnym razie podział ten

13 G. W. Leibniz, Dissertatio de arte combinatoria in qua ex arithmeticae fundamentis complicationum ac transpositionum doctrina novis praeceptis extruitur, et usus ambarum per universum scientiarum orbem ostenditur; nova etiam ars meditandi seu logicae inventionis semina sparguntur, w: G. W. Leibniz, Die Philosophischen Schriften von G. W. Leibniz, VII Vol., ed. C. I. Gerhardt, Halle 1849-1863 (repr. Hildesheim 1960), t. IV, s. $64-65$ (dalej: GP). 
byłby nieskończony. Analizując ten system definicji pojęć Leibniz doszedł do przekonania, że proces podziału na gatunki kończy się dopiero w chwili uzyskania całkowitego opisu jakiegoś indywiduum. Znaczy to, że najniższym pojęciem gatunkowym jest pojęcie indywidualne. Wynika stąd, że każdy najniższy gatunek nie może mieć więcej niż jeden podpadający podeń egzemplarz ${ }^{14}$. W rozprawie De principio individui Leibniz, przyjmując nominalistyczne założenie Suareza, iż nie ma i być nie może innych bytów niż jednostkowe, ustalił zasadę identyczności rzeczy nierozróżnialnych, zgodnie z którą nie mogą istnieć dwa identyczne indywidua ${ }^{15}$. Zasad ta odgrywała dużą rolę $w$ poglądach Leibniza. Wiązała się przede wszystkim z pojęciem uniwersalnej harmonii, implikującym systematyczną i harmonijną jedność poszczególnych bytów, z których dowolne dwa różnią się wewnętrznie od siebie, choćby nawet różnica ta była nieuchwytna.

Leibniz przyjmując istnienie elementarnych pojęć, które stanowiłyby alfabet ludzkiej myśli, założył, że można je zestawiać w nieograniczony sposób. Była to zatem idea zgodna $\mathrm{z}$ ideą rachunku. Zilustrował ją przykładem, w którym liczby 3, 6, 7 i 9 przedstawiają cztery proste pojęcia. Tworzą one pierwszą klasę pojęć. Drugą klasę nowych pojęć tworzy się przez kombinację kolejnych par prostych pojęć: 3·6, 3·7, 3·9, $6 \cdot 7,6 \cdot 9,7 \cdot 9$. Podobnie, dzięki kombinacji trójek, tworzy się klasę trzecią i następne. Jedną $z$ nich jest 3·6 9, która jest także $1 / 2 \cdot 9,2 / 3 \cdot 6$ lub 5/2 3 gdzie $m / n$ znaczy $m$-ty term $n$-tej klasy. Istnieje więc wiele wyrażeń tej samej rzeczy, których równoważność weryfikowana jest poprzez ich rozkład na składniki elementarne ${ }^{16}$.

Zauważmy, że oprócz zestawu pojęć elementarnych istotne znaczenie mają tu reguły zestawiania tych pojęć. W De arte combinatoria Leibniz przedstawia zarys kombinatoryki, ustanawiając reguły rachunku numerycznego relacji pomiędzy obiektami, usiłuje jednocześnie umieścić te relacje w perspektywie wykraczającej daleko poza sam rachunek. Kombinatoryka stanowiła dlań bowiem „metafizyczną doktrynę cało-

14 Taką interpretację przedstawia G. MacDonald Ross, w: Leibniz, Oxford, New York, s. 51-52.

15 G. W. Leibniz, Gothofredi Guiliemi Leibnitii Opera Omnia, nunc primum colleta... par Ludovicius Dudens, VI Vol., Genève 1767, II, s. 11-14.

16 De arte combinatoria, GP IV, 65. 
ści i części” 17. Leibniz przyjął, że „ponieważ wszystko, co istnieje lub co może być pomyślane, musi składać się z części rzeczywistych lub konceptualnych, cokolwiek różni się naturą, musi koniecznie różnić się tym, że ma inne części, stąd przydatność złożeń; lub przez inną budowę, stąd przydatność rozkładu. Pierwsze są orzekane ze względu na różnorodność materii, drugie $z$ uwagi na różnice formy" ${ }^{18}$. Na tej podstawie, jak twierdzi Leibniz, można odkryć nie tylko rodzaje rzeczy, ale także ich atrybuty, cała bowiem twórcza część logiki ugruntowana jest w złożeniach.

Podobnie jaki inni logicy jego czasów, Leibniz wyraźnie odróżniał logikę odkryć i logikę dowodu lub sądzenia. Dotychczas podstawowy sukces logiki polegał na formułowaniu reguł dowodu, takich jak te stosowane w sylogistyce Arystotelesa oraz w aksjomatycznej metodzie geometrii Euklidesa. Zasadniczą trudność stanowił jednak brak niezawodnych reguł, pozwalających tworzyć odkrywcze hipotezy.

Leibniz był całkowicie owładnięty wizją logiki odkryć, dostarczającej dowodów dla odkrytych praw. Dodatkowo wzmacniało ją przekonanie, że logika odkryć i logika dowodu wzajemnie się dopełniają. Ponieważ sądy prawdziwe są zawsze analityczne, symetria sugeruje, że proces odkrywania powinien być syntetyczny lub, używając leibnizjańskiego określenia, kombinatoryczny ${ }^{19}$. Myśl ta powraca w wielu jego pismach. Przedstawia ją, między innymi, w rozprawce $O$ powszechnej syntezie $i$ analizie, czyli o sztuce odkrywania $i$ sqdzenia. Leibniz wyjaśnia, że proces syntezy rozpoczyna się od zasad, prowadzących przez kolejno przebiegane prawdy do odkrywania nowych ciągów, układania $\mathrm{z}$ nich tabel i formuł, którymi można się będzie posłużyć $\mathrm{w}$ celu znalezienia rozwiązań i problemów, jakie się z czasem wyłonią ${ }^{20}$. Problemem

17 De arte combinatoria, GP IV, 36. Zob. Manuel Antonio Correia, De arte Combinatoria: Unity and Harmony in the Doctrine of the Whole and of the Parts, w: Leibniz und Europa VI. Internationaler Leibniz-Kongreß Vorträge I. Teil, Hannover 1994, s. 143-151.

18 De arte combinatoria, GP IV, 44.

19 Leibniz wierzył, że tak analityczne, jak i syntetyczne rozumowanie może być redukowane do czysto mechanicznych operacji, co więcej $-\mathrm{z}$ upływem czasu, jego zdaniem, wszystkie operacje kombinatoryczne staną się analityczne, jeśli wszyscy ludzie zaczną stosować jego metodę zestawień, C, 168. Zob. MacDonald Ross, Leibniz, s. 61.

20 De synthesi et analysi universali seu arte inveniendi, GP VII, 298 - O powszechnej syntezie $i$ analizie, czyli o sztuce odkrywania i sqdzenia, przekład M. Gordon, w: M. Gordon, Leibniz, Warszawa 1973, s. 235. 
staje się tu w istocie sam dobór pojęć pierwotnych, gdyż ten dokonuje się czysto arbitralnie ${ }^{21}$. Leibniz analizując ten problem, wskazuje na konieczność posługiwania się kryteriami wyraźności i jasności, zabezpieczającymi - jego zdaniem - przed przyjęciem pojęć sprzecznych ${ }^{22}$. Sam proces syntezy pojęć nie jest arbitralny, gdyż każde nowo utworzone pojęcie złożone musi być pojęciem możliwym ${ }^{23}$. W omawianej pracy Leibniz ujmuje tzw. alfabet myślenia jako katalog rodzajów najwyższych, z których kombinacji powstawałyby pojęcia niższego rzędu. Pojęcia te $z$ natury bardziej szczegółowe tworzyłyby gatunki niższych rzędów, także te, które są jedynie możliwe.

Leibniz traktował kombinatorykę jako naukę o możliwych formach czy strukturach przedmiotowych. $W$ tym rozumieniu była ona nauką ogólną (science générale). Nauka ogólna powinna - jego zdaniem - „dostarczyć nie tylko sposobu posługiwania się wiedzą już zdobytą, ale ponadto metody sądzenia i wynajdywania, aby można pójść dalej i uzupełnić to, czego nam brakuje" 24 . Językiem tej nauki powinien być system znaków jednoznacznie odwzorowujący wszystkie dziedziny przedmiotowe tej nauki - characteristica generalis.

Komentując Kartezjusza, Leibniz był przekonany, że język ten jest niemal w zasięgu ręki. Część pracy miał już za sobą - doskonałą strukturę językową; na mocy założenia, że pierwotnymi składnikami rzeczywistości są substancje i ich własności Leibniz uznał, że najwłaściwsza struktura językowa, odzwierciedlająca zawieranie się własności w substancji, to forma podmiotowo-orzecznikowa; oraz - kombinatorykę, która uogólniona stanowiła wzorzec nauki ogólnej, oparty na teorii logicznej i matematycznej. Kombinatoryczne podejście wiązało się

21 Pierwotna wartość znaku (charakteru), ta, która została nadana mu arbitralnie i nie wymaga uzasadnienia stanowi jego znaczenie (significatio). Podstawy formalizacji rozumowań (Fundamenta calculi ratiocinatoris, GP VII, 45), w: M. Gordon, Leibniz, s. 251.

22 O powszechnej syntezie $i$ analizie, czyli o sztuce odkrywania $i$ sadzenia, w: M. Gordon, Leibniz, wyd. cyt., s. 230. Leibniz wyjaśnia dalej (s. 232), że "Nie możemy [...] beztrosko budować dowodu na rzecz jakiegoś pojęcia, jeżeli nie wiemy, czy jest ono możliwe".

23 O powszechnej syntezie $i$ analizie..., w: M. Gordon, Leibniz: „Chociażby, wreszcie, nadawanie nazw było dowolne, jednakże konsekwencje ich zestawień (iis semel positis) są konieczne i rodzą się z nich prawdy, które jakkolwiek mają ważność (pendent) w oparciu o ustanowione charaktery, są jednak realne", s. 233.

24 C, 228, przekład S. Cichowicz, w: G. W. Leibniz, Wyznanie wiary filozofa..., Warszawa 1969, s. 469 . 
z wizją niezmienności zbioru wyjściowych pojęć konstytuujących całość wiedzy. Całe poznawcze przedsięwzięcie kombinatoryki polegało na poszukiwaniu zestawień tych pojęć tworzących sądy prawdziwe. Kluczowa dla całej procedury była dla Leibniza jego Zasada Identyczności. Zgodnie $\mathrm{z}$ nią dany sąd jest sądem prawdziwym, jeśli jest sądem identycznościowym lub jest do niego redukowalny. Sąd identycznościowy to taki, w którym predykat jest identyczny $\mathrm{z}$ podmiotem lub się $\mathrm{w}$ tym podmiocie zawiera, na przykład $a$ jest $a$ lub ab jest $a$. Można powiedzieć więc, że każdy sąd prawdziwy jest prawdziwy na mocy swojej formy i jako taki jest zdaniem analitycznym. Leibniz dokonał wyraźnego rozróżnienia pomiędzy prawdami rozumowymi a prawdami faktycznymi. Te pierwsze są twierdzeniami koniecznymi w tym sensie, że albo same są twierdzeniami oczywistymi, albo są do nich redukowalne. Wszystkie prawdy rozumowe są $\mathrm{z}$ konieczności prawdziwe, a prawdziwość ich opiera się na zasadzie sprzeczności - czy też, co jego zdanie wychodzi na to samo - zasadzie tożsamości ${ }^{25}$. Prawdy faktyczne natomiast nie są twierdzeniami koniecznym, ale są także $w$ jakimś sensie analityczne. Dla Leibniza „indywidualność ogarnia sobą nieskończoność, i ten tylko, kto to zdolny jest pojąć, może poznać zasadę indywidualizacji tej czy innej rzeczy..." 26. Żaden skończony umysł nie może dokonać tej analizy, zatem „pewność i doskonała racja prawd przygodnych jest znana tylko Bogu, który ogarnia nieskończoność jednym aktem intuicji" 27. Można powiedzieć więc, że różnica między prawdami rozumowymi a prawdami faktycznymi odnosiła się u Leibniza zasadniczo do kwestii ludzkiego poznania. Wynika stąd, że w przypadku sądów empirycznych o indywiduach liczba predykatów zawartych $\mathrm{w}$ podmiocie jest nieskończona i znana jedynie Bogu; ale w zasięgu ludzkich możliwości jest „rozbiór tego, co konieczne, tj. analiza esencji” ${ }^{28}$. Leibniz dał więc wyraz przekonaniu, że analiza zdań ogólnych pozwala na utworzenie listy wyjściowych pojęć pierwotnych, których zestawienia będą

\footnotetext{
25 Zob. T. Czeżowski, Odczyty filozoficzne, Toruń 1969, s. 154.

26 G. W. Leibniz, Nowe rozważania dotyczące rozumu ludzkiego, tłum. I. Dąbska, Warszawa 1955, t. II, s. 32.

27 GP VII, 309.

28 Zob. F. Copleston, Historia filozofii, tłum. J. Marzęcki, Warszawa 1995, t. IV, s. 279.
} 
stanowić podstawę dla ogarnięcia całości ludzkiej wiedzy. Można w tym miejscu zapytać o charakter tej listy, mianowicie: czy wyjściowych pojęć jest nieskończenie czy skończenie wiele? Leibniz, niestety, nie wypowiadał się $\mathrm{w}$ tej kwestii precyzyjnie. Zestawienie pojęć pierwotnych z liczbami całkowitymi wskazuje, że jest ich przeliczalnie nieskończenie wiele ${ }^{29}$, ale definicja zbioru tych pojęć jako „alfabetu myśli” 30 pozwala zakładać, że Leibniz miał na uwadze pewien zbiór skończony, na mocy faktu, że aktualny umysł dysponuje wiedzą, która zawiera skończoną liczbę elementarnych składników myślenia, choć potencjalnie jest zdolny do rozwijania jej w sposób nieskończony.

Istotny dla usprawnienia czynności poznawczych był leibnizjański postulat inwentaryzacji „całej wiedzy nabytej, lecz rozproszonej i źle uporządkowanej" ${ }^{31}$, a przynajmniej tej, która wydaje się najważniejsza. Kryterium rozstrzygającym o przynależności zdań do tak pomyślanego zbioru jest przyjmowanie tylko tych, których prawdziwość jest dowiedziona, gdyż prawdziwa „wiedza zależy od dowodu” 32 . Problemem staje się $\mathrm{w}$ tym miejscu sam dowód, gdyż wymaga on znajomości prawdziwej metody, która, "wzięta w całej rozciągłości”, jest - zdaniem Leibniza - jeszcze „rzeczą całkowicie nieznaną" ${ }^{33}$. Nie ulega jednak wątpliwości, że fundamentem zbioru zdań składających się na katalog ludzkiej wiedzy są dla Leibniza prawdy logiczne i matematyczne. Bowiem, „jeśli metoda matematyków nie wystarczyła do odkrycia wszystkiego [...], to przynajmniej zdołała uchronić ich od błędów; jeśli zaś nie powiedzieli wszystkiego, co powinni, to nie powiedzieli również tego, czego mówić nie powinni" 34 .

Matematyka stanowiła, zdaniem Leibniza, wzorzec dla innych nauk. „Gdyby ci, którzy uprawiali inne nauki, naśladowali matematyków [...], już dawno mielibyśmy metafizykę pewną, jak również etykę, od której wszystko zależy [...], oprócz tego naukę o ruchach, która

\footnotetext{
29 C, 187.

$30 \mathrm{C}, 430$.

31 C, 229.

32 G. W. Leibniz, Przedmowa do nauki ogólnej, w: Wyznanie wiary filozofa..., s. 69.

33 Tamże, s. 69.

34 Tamże, s. 69-70.
} 
stanowi klucz do fizyki, a przeto i do medycyny"35. Piękno matematyki polega bowiem na tym, że zbudowana $\mathrm{z}$ jednoznacznych symboli nie musi dla przeprowadzenia dowodów wychodzić poza swój własny system znakowy i na nich, a nie na rzeczach przeprowadza swoje operacje. Matematyka opisuje pewne dziedziny przedmiotowe, ale dzięki jednoznaczności odwzorowującego te dziedziny symbolicznego języka $\mathrm{w}$ swoich działaniach może ograniczyć się do wybranej symboliki. „Gdyby w innych dziedzinach równie łatwo było wykryć [...] prawdę rozumowań, nie byłoby tak wielu rozbieżnych przekonań" 36 . Wynika stąd, że "gdyby dało się wynaleźć znaki graficzne lub umowne (caractères ou signes) nadające się do wyrażania naszych myśli równie jasno i ściśle, jak arytmetyka wyraża liczby lub analiza geometryczna linie, to można byłoby w każdej dziedzinie - o ile tylko podlega ona rozumowaniu - zrobić wszystko, co można zrobić $\mathrm{w}$ arytmetyce lub geometrii" ${ }^{37}$.

\section{Próby konstrukcyjne}

Inspirowany symboliką matematyczną, Leibniz podjął wstępne prace nad ustaleniem zestawu pojęć wyjściowych i odpowiedniej dla nich notacji. Eksperymentował $\mathrm{z}$ wieloma systemami. $\mathrm{W}$ jednym $\mathrm{z}$ projektów zaproponował użycie liczb pierwszych na oznaczenie pojęć pierwotnych. Ich iloczyny tworzyłyby pojęcia złożone. Tak więc, jeśli zwie$r z \varepsilon=2$, rozumne $=3$, to człowiek $=6=2 \times 3^{38}$. Język ten nie satysfakcjonował jednak Leibniza. Nie spełniał on jednego $\mathrm{z}$ podstawowych wymagań; struktura symboli powinna odpowiadać bowiem strukturze znaczeń, ale bardzo duże liczby nie ujawniają $w$ sposób oczywisty swoich składników, trudno jest więc ukazać $\mathrm{w}$ zrozumiały sposób zawieranie się orzeczeń $\mathrm{w}$ podmiocie, co jest możliwe $\mathrm{w}$ przypadku krótszych zestawień. Nie jest też zupełnie jasne, według jakich kryteriów Leibniz dokonywał wyboru pojęć pierwotnych. Trudno je także

\footnotetext{
35 G. W. Leibniz, Przedmowa do nauki ogólnej, w: Wyznanie wiary filozofa..., s. 70.

36 Tamże, s. 70.

37 Tamże, s. 72.

38 Zob. L. Couturat, La Logique de Leibniz, Paris 1901, s. 62 oraz GP VII, 78, przypis 1.
} 
rozpoznać w projekcie $\mathrm{z}$ lutego $1678 \mathrm{r} .{ }^{39}$ Sam Leibniz, świadomy praktycznych trudności $\mathrm{w}$ wytłumaczeniu potencjalnym jego użytkownikom potrzeby stosowania języka uniwersalnego, chciał ich przekonać systemem, który spełniałby wymagania elegancji i prostoty. Zaproponował więc zastosowanie spółgłosek, które odpowiadałby dziewięciu cyfrom w następujący sposób:

$\begin{array}{lllllllll}1 & 2 & 3 & 4 & 5 & 6 & 7 & 8 & 9 \\ \text { B } & \text { C } & \text { D } & \text { F } & \text { G } & \text { H } & \text { L } & \text { M } & \text { N }\end{array}$

oraz użycie samogłosek, które wyrażałby miejsce dziesiętne cyfry:

$\begin{array}{ccccc}1 & 10 & 100 & 1000 & 10000 \\ \mathrm{~A} & \mathrm{E} & \mathrm{I} & \mathrm{O} & \mathrm{U}\end{array}$

Dyftongi mogłyby być stosowane dla wyrażenia wyższych potęg liczby 10 . Tak więc na przykład liczbę 81374 oznaczałoby mubodilefa. Niezwykłość i piękno tego prostego pomysłu polegało, zdaniem Leibniza, na tym, że ta sama liczba może być wyrażona także słowem bodifalemu, gdzie miejsce dziesiętne cyfry wskazują samogłoski lub famuledibo czy lebomufadi. W rzeczywistości istnieje 120 permutacji tego pięciosylabowego słowa. Ten zawrotny wybór pełnych synonimów tworzy ogromne możliwości wyrażania. Pozwala, co według Leibniza jest jedną $\mathrm{z}$ największych zalet tego systemu, tworzyć najbardziej subtelne poematy $\mathrm{z}$ zachowaniem tego samego znaczenia ${ }^{40}$.

Kierując się kryterium estetycznym Leibniz rozważał także możliwość zastosowania zapisu muzycznego ${ }^{41}$. O tym, że projekt ten nigdy nie doczekał się realizacji, świadczy uwaga autora zawarta w Nowych rozważaniach..., że „można by mówić, tzn. dawać się słyszeć za pomocą dźwięków z ust, bez tworzenia dźwięków artykułowanych, gdyby się posługiwano do tego celu tonami muzycznymi; ale większą byłoby sztuką wynaleźć mowę tonów..." 42.

\footnotetext{
39 C, 277-278.

40 C, 277-278, zob. też L. Couturat, La Logique de Leibniz, s. 62-63.

41 C, 280: „Omnino autem cogitandum de lingua hac per Musicam exprimenda. Hoc enim eam pulcherrimam reddere potest, et nihilominus opus magna libertate, ut liceat in ea exhibere pulchra carmina et animum moventia".

42 G. W. Leibniz, Nowe rozważania.., t. II, s. 8.
} 
Choć większość eksperymentów Leibniza wydaje się fragmentaryczna i zupełnie nieprzystająca do ideologii całego przedsięwzięcia, którego celem był doskonały język uniwersalny, to na uwagę zasługuje system przedstawiony $\mathrm{w}$ Generales inquisitiones de Analysi Notionum et Veritatum ${ }^{43}$, który jest algebraicznym ujęciem relacji między pojęciami. System ten nazwany przez Leibniza rachunkiem pojęć (calculus ratiocinator, calculus universalis) jest formalnym dedukcyjnym systemem konstytuującym część nauki ogólnej (scienta universalis). Leibniz zauważył, że logika dotyczy w istocie klas rzeczy lub pojęć. Różnica między podmiotem a orzecznikiem, jakkolwiek ważna $\mathrm{z}$ gramatycznego punktu widzenia, nie ma większego znaczenia w logice. Podmiot może bowiem równie dobrze wystąpić jako orzecznik i vice versa: np. zamiast "Każdy człowiek jest rozumny”, można powiedzieć, że „Rozumność jest konstytutywną cechą człowieczeństwa". Prowadzi to jednak - jak zauważył Leibniz - do zasadniczych różnic $\mathrm{w}$ sposobie ujęcia relacji między podmiotem i orzecznikiem, $\mathrm{w}$ zależności od tego, czy rozważane są one jako denotujące klasy, czy też pojęcia. Jeśli weźmiemy pod uwagę schemat zdania ogólnego o postaci "Każde $S$ jest $\mathrm{P}^{\prime \prime}$, to interpretowany intensjonalnie (czyli pojęciowo) znaczy, że pojęcie $S$ zawiera $\mathrm{w}$ sobie pojęcie P. Rozważany natomiast ekstensjonalnie (czyli zakresowo) znaczy, że klasa $S$ jest podklasą klasy P. Wybierając interpretację intensjonalną, Leibniz kierował się pewnymi założeniami filozoficznymi, utrzymywał bowiem, że podmioty zdań są $\mathrm{w}$ istocie wysoce złożonymi predykatami, zawierającymi $\mathrm{w}$ sobie wszystkie możliwe orzeczniki, które da się o tym podmiocie wypowiedzieć. Nie będziemy tu wchodzić $\mathrm{w}$ szczegóły techniczne systemu wyłożonego w Generales inquisitiones, warto jednak zwrócić uwagę na systematyczne stosowanie przez Leibniza zmiennych w sposób pozwalający odnosić je do obiektów dowolnego rodzaju, a przede wszystkim algebraiczne ujęcie zależności pomiędzy zdaniami ogólnymi i ich przekładem na zdania egzystencjalne. Wprowadzając zwroty: 'est ens' (istnieje) i 'non est ens' (nie istnieje), używał je Leibniz w znaczeniu, które, jak twierdzi wielu badaczy, antycypuje system algebry Boole'a - 'est

43 C, 356-399, zob. także G. W. Leibniz, Allgemeine Untersuchungen über die Analyse der Begriffe und Wahrheiten, Felix Meiner Verlag, Hamburg 1982 i zawarty tam komentarz oraz bibliografia. 
ens' równoważne jest bowiem $\mathrm{z} ' \neq 0$ ', 'non est ens' rozumieć można jako ' $=0$ ' 44 .

\section{Przebudowa języka łacińskiego}

Być może brak wyraźnego postępu w pracach nad stworzeniem od podstaw języka, który byłby twórczym narzędziem rozwijania ludzkiej wiedzy, spełniającym ponadto kryteria estetyczne, sprawil, że Leibniz zdecydował się zaatakować problem $\mathrm{z}$ innej strony, zwracając swoją uwagę na łacinę - międzynarodowy język nauki. Wierzył, że reforma istniejącego języka pozwoli na oczyszczenie go z właściwych wszystkim językom etnicznym zjawisk, prowadzących do błędów w słownym formułowaniu myśli: amfibolii, ekwiwokacji etc., pozwoli także wyeliminować wszelkie nieregularności. Pierwszym krokiem takiej reformy było uproszczenie całej gramatyki. Leibniz odwołał się tu do pewnych wzorców, których dostarczył stworzony na bazie włoskiego język stosowany $\mathrm{w}$ handlu śródziemnomorskim - linqua franca, a także uproszczony język przedstawiony przez jezuitę francuskiego Philippa Labbé w pracy Grammatica Linquae universalis z 1663 r. W Nowych rozważaniach... wspomniał także o uproszczonym systemie języka łacińskiego pewnego armeńskiego dominikanina, którego spotkał podczas swojego pobytu $\mathrm{w}$ Paryżu ${ }^{45}$. Niewątpliwie argumentem na rzecz redukcji systemu gramatycznego była tu łatwość jego opanowania, ale wydaje się, że motywy, którymi kierował się Leibniz, miały głębsze podłoże filozoficzne. Jeżeli bowiem świat rzeczywisty składa się wyłącznie $\mathrm{z}$ substancji i ich akcydensów, to może on być opisany przez zbiór zdań o postaci 'A est $B$ ', gdzie $A$ jest kompletnym indywidualnym pojęciem danej substancji, zaś $B$ jej akcydensem. Wobec tego wszystkie sądy, które mają inną postać, powinny być redukowalne do tego schematu.

\footnotetext{
44 Zob. W. Marciszewski, R. Murawski, op. cit., s. 81-82, a także M. Juniewicz, Analycity of Truths and the Problem of Decidability in Leibniz's Logic, "Studies in Logic, Grammar and Rhetoric" VII, Białystok 1988, s. 49-81.

45 G. W. Leibniz, Nowe rozważania..., t. II, s. 15.
} 
Uproszczenie gramatyki polegać miało na całkowitej rezygnacji z fleksji. Modelem były tu dla Leibniza tzw. języki analityczne, czyli te, $\mathrm{w}$ których wszystkie wyrazy są nieodmienne ${ }^{46}$. Leibniz dowodzil, że fleksja jest redundantna $\mathrm{w}$ języku, który posiada partykuły, takie jak: przyimki, spójniki i zaimki47, na przykład: „przypadki odpowiadają przyimkom, a często przyimek zawarty jest $\mathrm{w}$ nazwie i przez nią pochłonięty" 48 .

Reformie ulec powinna także liczba części mowy ${ }^{49}$. Leibniz postulował między innymi redukcję rzeczowników do przymiotników określających byt czy rzecz (Ens lub Res): Idem est Homo quod ens humanum; przysłówki do przymiotników (imiesłowów) lub rzeczowników odczasownikowych (zamiast valde potio, sum magnus potator) oraz wszystkie czasowniki do czasownika est ${ }^{50}$. W wyniku tej redukcji otrzymujemy słownik składający się z jednego rzeczownika oznaczającego rzecz, jednego czasownika oraz listy przymiotników. Do tego zestawu wyrażeń dołącza Leibniz partykuły. Dzięki tej klasie wyrażeń, zwłaszcza po odrzuceniu fleksji, zyskujemy możliwość łączenia wyrażeń w złożone całości. Partykuły bowiem "wiążą nie tylko części przemówienia złożonego ze zdań i części zdania, złożonego $\mathrm{z}$ idei, ale nadto i części idei, złożonej w liczne sposoby przez zestawianie $z$ sobą innych idei". Wprawdzie partykuły należą do słownika, ale reguły ich stosowania wyznaczają gramatykę tak uproszczonego języka. Leibniz pisze zresztą wprost, że "Słowa należą do Słownika, partykuły zaś do Gramatyki" (Voces pertinet ad Dictionarium, particulae ad Grammaticam) ${ }^{51}$. Reformę gramatyki uzasadnia Leibniz następująco:

\footnotetext{
46 Analityczność języków jest sprawą stopnia, typowymi językami izolującymi są wietnamski i chiński. Zob. J. Lyons, Wstęp do językoznawstwa, przekład K. Bogacki, Warszawa 1975, s. 212. Leibniz żywo interesował się chińskim, dziwić więc może, że zamiast zająć się tym językiem, poszedł w kierunku reformowania łaciny. O szczególnym stosunku Leibniza do języka chińskiego i planach $\mathrm{z}$ nim związanych piszę nieco dalej.

47 L. Couturat, La Logique de Leibniz, s. 67-68. Zob. także D. P. Walker, Leibniz and Language, "Journal of the Warburg and Courtauld Institutes", Vol. 35, 1972, s. 298.

48 G. W. Leibniz, Nowe rozważania..., t. II, s. 101.

49 L. Couturat, La Logique de Leibniz, s. 67-68.

50 C, 281. Zob. L. Couturat, La Logique de Leibniz, s. 70.

51 M. Dascal, Leibniz on Particle, w: T. de Mauro, L. Formigari (ed.), Leibniz, Humboldt, and the Origines of Comparativism, Amsterdam Philadelphia 1990, s. 56.
} 
„Rozróżnienie rodzaju nie jest istotne dla gramatyki filozoficznej; ani też rozróżnienie pomiędzy deklinacją i koniugacją nie ma żadnego zastosowania $\mathrm{w}$ gramatyce filozoficznej. Tak więc odróżniamy rodzaje, deklinacje i koniugacje bez żadnego pożytku, bez korzyści dla zwięzłości - może jedynie to zróżnicowanie jest przyjemne dla ucha; ale te rozważania nie dotyczą filozofii, zwłaszcza, że chcemy dodać piękna językowi racjonalnemu inną metodą, tak że nie będzie konieczne zastanawiać się nad bezużytecznymi regułami" 52 .

Na mocy założenia, że Vocabula sunt voces aut particulae, słowa konstytuują rzecz, partykuły formę dyskursu ${ }^{53}$, zasadniczą kwestią staje się analiza i klasyfikacja zaliczonych do tej klasy wyrażeń ${ }^{54}$. Leibniz wielokrotnie podkreślał poznawczy aspekt tego przedsięwzięcia. Jeśli we wcześniejszych pracach traktował partykuły jako formę dyskursu, to $\mathrm{w}$ Nowych rozważaniach... stają się one już formami samego myślenia ${ }^{55}$. Dascal w szkicu pt. Leibniz on Particles ${ }^{56}$ rekonstruuje jego program badawczy, wskazując między innymi, że dla Leibniza najważniejsza jest zasada oszczędności, która oznacza redukcję wielości, nieporządku i złożoności do jedności, regularności i prostoty. Wynika z niej bezpośrednio dyrektywa poszukiwania regularnych znaczeń oraz potrzeba konstruowania takich definicji partykuł, które ujawniałyby ich wzajemną zastępowalność 57 .

Leibniz odrzucił tradycyjne morfologiczne kryterium niedeklinowalności, które stosowali gramatycy, kierując się raczej kryteriami funkcjonalnymi. Partykułami były dlań te wyrażenia, które pełniły wszelką funkcję pomocniczą. Nie wyjaśniał jednak bliżej jak należy rozumieć naturę owej funkcji, co czyniło klasę partykuł wielce niejednorodną.

52 Cytat za: Robert Mc Rae, Locke and Leibniz on Linguistic Particles, „Synthese”, Vol. 75, May 1988, No. 2, s. 13. Nie pokrywa się ze wskazaniami bibliograficznymi.

53 C, 288.

54 R. Mc Rae, op. cit., s. 155-163.

55 G. W. Leibniz, Nowe rozważania..., t. II, s. 101.

56 M. Dascal, Leibniz on Particles, w: Leibniz, Humboldt, and the Origines of Comparativism, s. 35.

57 Leibniz tłumaczy, że: „Aby dobrze wyjaśnić partykuły, nie wystarczy abstrakcyjne ich tłumaczenie [...], lecz trzeba się uciec do omówienia, które by mogło je zastąpić, jak definicja może zastapić miejsce tego, co definiowane. Kiedy się będzie dbało o wyszukiwanie i ustalanie tych możliwych do podstawienia omówień dla wszystkich partykuł, o ile tylko są temu dostępne, wówczas unormuje się ich znaczenia", Nowe rozważania..., t. II, s. 103. 
Na przykład do klasy tej włączone były, jako pomocnicze, zaimki quis i ille, czasowniki sum i habeo, przysłówki quomodo i sic oraz oczywiście przedimki i spójniki ${ }^{58}$.

Zwróćmy uwagę, że choć kryterium pełnienia funkcji pomocniczej nie odbiega zasadniczo od średniowiecznego podziału na wyrażenia kategorematyczne i synkategorematyczne, to Leibniz modyfikuje zakres tej ostatniej klasy wyrażeń, włączając doń te, które gramatica speculativa traktowała jako samodzielne znaczeniowo i niezbędne dla utworzenia zdania. Kryterium wskazane przez Leibniza nie rozstrzyga, czy wyrażenie pozbawione jest znaczenia. Co więcej, postulat analizy regularnych znaczeń implikuje, że partykuły pełnią pewne funkcje znaczeniowe. Leibnizjańskie kryterium niesamodzielności bliskie jest podziałowi wyrażeń na kategorie podstawowe i kategorie wyrażeń niesamodzielnych, przyjętemu we współczesnej semiotyce logicznej. Można dostrzec tu pewną analogię między wskazaną przez Leibniza klasą partykuł a klasą wyrażeń funktorowych. Wyraźnie wskazuje on bowiem na różnice między przyimkami, które łączą nazwy, a spójnikami, które łączą zdania. „Praepositiones jungunt nomina, conjunctiones jungunt integras propositiones" 59 . Według Leibniza jedyną klasą wyrażeń, które są znakami pojęć, są nazwy, reszta to sposoby ujęcia rzeczy (to semantyczne kryterium przedstawia Leibniz w szkicu Characteristica verbalis $\left.{ }^{60}\right)$, zaś podstawą wszelkich czynności poznawczych stanowi sąd podmiotowo-orzecznikowy. Mamy tu zatem do czynienia z propozycją znacznego uproszczenia systemu językowego, połączoną $\mathrm{z}$ próbą uzgodnienia kategorii znaczeniowych $\mathrm{z}$ kategoriami gramatycznymi.

58 M. Dascal, Leibniz on Particles, w: Leibniz, Humboldt, and the Origines of Comparativism, s. 39. Dascal analizuje leibnizjański system partykuł, odwołując się do tekstów Leibniza opublikowanych w zbiorze pt. G. W. Leibniz - Vorausedition zur Reihe VI - Philosophische Schriften. Manusktriptdruck, Leibniz-Forsungstelle der Universität Münster, 1982. Nie mając, niestety, dostępu do tej pracy, referuję ten system na podstawie opracowania Dascala, które jest najpełniejszym, znanym mi ujęciem studiów Leibniza nad partykułami.

59 Zob. M. Dascal, Leibniz on Particles, w: Leibniz, Humboldt, and Origines of Comparativism, s. 54, przypis 30 .

60 "Vocabula sunt signa vel Conceptum, ut Nomina, vel modorum concipiendi, ut caeterae partes orationis" (Słowa są znakami pojęć, jak w przypadku nazw, lub sposobami pojmowania, jak w przypadku innych części mowy): C, 432; "Modi concipiendi designatur particulis” (Sposoby pojmowania desygnowane są przez partykuły): C, 434. 
Pojawia się jednak pewna niekonsekwencja. Otóż Leibniz analizując naturę partykuł pisze, że $\mathrm{w}$ języku filozoficznym partykuły, afiksy i końcówki nie są wyszczególnione, a zatem każda część słowa będzie słowem ${ }^{61}$. Uwaga ta jest zaskakująca, gdyż przyjmując jako model wyjściowy języki analityczne, Leibniz założył jednocześnie, że projekt przebudowy języka łacińskiego polegać będzie, przynajmniej $w$ fazie wstępnej, na usunięciu redundantnej wobec partykuł fleksji. Można przypuszczać, że Leibniz, kierując się zasadą oszczędności, kolejnym etapem redukcji uczynił cały zestaw wyrażeń pomocniczych, dążąc do zastąpienia ich wszystkich konstrukcjami, które sprowadzałyby się do formy podmiotowo-orzecznikowej, na przykład:

Titius est magis doctus Caio równoważne jest, według Leibniza, ze zdaniem: Quatenus Titius est doctus, et Caiues est doctus, eatenus Titius est superior et Caius est inferior, a zatem Titius est doctus, et qua talis est superior, quatenus inferior qua doctus est Caius ${ }^{62}$.

Petrus scribit pulchre: Petrus scribit aliquid pulchrum < seu Petrus scribit (lub Petrus est scribens), et quod Petrus scribit est pulchrum ${ }^{63}$.

Paris est amator Helenae: Paris amat (et eo ipso) Helena amatur64.

Homines scribunt: Titius est scribens, Caius est scribens. Titius est homo. Caius est homo ${ }^{65}$.

Termin redukcja rozumiany był przez Leibniza bardzo szeroko. Czasem odnosił się on do redukcji trybów jednego sylogizmu do drugiego, czy też ogólnej, redukcji jakiegoś problemu do innych. Proces ten dotyczył także zdań. Poza wskazanymi wyżej próbami, Leibniz podaje wiele przykładów takich przekształceń. I tak:

Quidam homo est doctus upraszcza się do Homo doctus est ens.

Nullus homo est lapis: Homo lapis est non Ens.

Quidam homo non est doctus: Homo non doctus est Ens ${ }^{66}$.
61 C, 433.
62 C, 280.
63 C, 244.
64 C, 287.
65 C, 244.
66 C, 323. 
Celem tych analiz było przede wszystkim zachowanie logicznej równoważności zdań poddanych redukcji $\mathrm{z}$ ich odpowiednikami. Trudno natomiast o spełnienie tego wymogu $w$ innych przypadkach, dyskusyjna jest choćby równoważność zdania Homines scribunt ze wskazaną przez Leibniza koniunkcją zdań jednostkowych, z uwagi na jego eliptyczny charakter. Można bowiem interpretować je jako zdanie ogólne: Omnes homines scribunt, zdanie egzystencjalne: Quidam homines scribunt, lub zdanie, w którym nazwa homines występuje jako nazwa gatunku. Wydaje się jednak, że choć tzw. analiza redukcyjna była dla Leibniza jednym ze środków prowadzących do utworzenia gramatyki języka uniwersalnego, to $\mathrm{w}$ równym stopniu służyła jako metoda poszukiwania regularności struktur językowych $w$ istniejących językach etnicznych. Ta regularność zwana jest przez Leibniza także uniwersalnością lub racjonalnością ${ }^{67}$ i obejmuje wszystko, co jest $w$ języku ogólne ${ }^{68}$. W tym znaczeniu analiza redukcyjna nie zawsze prowadzi do przekształceń, które spełniają kryteria równoważności logicznej, pozwala natomiast dostrzec ogólny charakter pewnych form językowych i jako taka przygotowuje grunt do poszukiwań uniwersalnych struktur logicznych ${ }^{69}$.

7.4.2. Warto wspomnieć tu o innych źródłach inspiracji Leibniza. Niezależnie od samodzielnych prób konstrukcyjnych, pozostawał on pod pewnym wpływem tradycji hermetycznej, studiował pisma alchemików, pitagorejską numerologię, kabalistykę ${ }^{70}$. Nie krył swojej fascynacji ideogramami i kryptogramami, prowadząc intensywne studia nad językiem chińskim, miał nadzieję na odkrycie klucza, który do-
67 C, 35.
68 C, 353.

69 Zob. M. Dascal, Leibniz on Particles, w: Leibniz, Humboldt, and the Origines of Comparativism, s. 49.

70 GP VII, 184: „Jam inde a Pythagora persuasi fuerunt homnies maxima in numeris mysteria latere. Et Pythagoram credibile est, ut alia multa, ita hanc quoque opinionem ex Oreinte attulisse in Graeciam. Sed cum vera arcani clavis ignoraretur, lapsi sunt curiosiores in futilia et superstitiosa, unde nata est Caballa quaedam vulgaris, avea longa remota, et ineptiae multiplices cujusdam falsi nominis Magiae quibus pleni sunt libri. Interea insita mansit hominibus facilitas credendi mirifica inveniri posse numeris, characteribus et lingua quadam nova, quam aliqui Adamicam, Jacobus Bohemus die Natursprache vocat. Sed nescio an quisquam mortalium veram rationem hactenus perspexerit, qua cuique rei numerus suus characteristicus assgnari possit. Nam euruditissimi homines cum aliquid hujusmodi obiter apud ipsos attigissem, fassi sunt non intelligere quid dicerem". 
prowadziłby go do rozpoznania prawdziwego, naturalnego związku między znakami i pojęciami. W jednym z listów do ojca Bouvet, misjonarza jezuickiego w Chinach, dostarczającego Leibnizowi materiału do badań, pisał, że nowy język, który planuje jako cudowny rachunek umysłu, będzie kontynuacją systemu znaków zawartego w księdze I - Ching, przypisywanej legendarnemu cesarzowi Fohi. Będzie to także szczególny język najwyższej kasty, najbardziej oświeconych intelektualistów ${ }^{71}$.

\section{Idea języka uniwersalnego w XVII wieku}

Jeśli analizujemy leibnizjańską ideę języka uniwersalnego, to pamiętać musimy, że idea ta wyrosła na pewnym gruncie cywilizacyjnym i kulturowym Europy XVII wieku. Odkrycia geograficzne, rozwój ekonomiczny, pociągający za sobą ożywioną wymianę handlową, potrzeba komunikacji językowej pomiędzy Europą i resztą świata, a także rozwój języków narodowych to tylko niektóre przyczyny decydujące o zaangażowaniu badaczy $w$ prace nad skonstruowaniem języka, który sprostałby zarówno potrzebom życia codziennego - jako międzynarodowy system komunikacji - jak i spełniałby wymagania stawiane językowi nauki. Leibniz konkurował na tym polu $\mathrm{z}$ wieloma innymi i trzeba wyraźnie powiedzieć, że przypisywanie mu prekursorstwa czy też wyjątkowej roli $w$ tej dziedzinie jest, jeśli nie bezpodstawne, to co najmniej dyskusyjne.

Wiek XVII można bez popadania w nadmierną przesadę nazwać epoką projektów języka uniwersalnego ${ }^{72}$. Poszukiwania i próby konstrukcyjne szły w różnych kierunkach: jedne skupiały się na badaniach i porównywaniu języków istniejących w celu wskazania systemu najdoskonalszego, inne to projekty uproszczenia wybranych języków etnicznych, jeszcze inne to ambitne plany budowy języka od podstaw. Leibniz próbował każdego z tych sposobów. Studia porównawcze nad językami

\footnotetext{
71 Zob. R. F. Merkel, Leibniz und China, w: Leibniz zu seinem 300. Geburstag, Berlin 1952, s. 55.

72 Historię różnych projektów języka uniwersalnego obszernie wykłada M. Jurkowski w książce Od Wieży Babel do języka kosmitów, Białystok 1986.
} 
etnicznymi doprowadziły go do wniosku, że u ich źródeł leżał jakiś język pierwotny o własnościach spełniających być może wymogi języka uniwersalnego, język zwany przez niektórych Adamowym, ale jego rekonstrukcja jest zupełnie niemożliwa. Trudno tu jednak o całkowitą konsekwencję, czasami bowiem twierdził, że język ten odzwierciedlał jedynie stan zaawansowania poznawczego pierwotnych społeczeństw, a barbarzyńcy mieli więcej instynktu niż rozumu. W dyskusji nad prymatem historycznym i kulturowym języków dał się ponieść emocjom twierdząc, że najbliższy Adamowemu jest język niemiecki i ten właśnie spełnia kryteria języka filozoficznego. Tak radykalne stanowisko $\mathrm{w}$ tej kwestii uległo osłabieniu pod wpływem zetknięcia się $\mathbf{z}$ cywilizacją Dalekiego Wschodu. Leibniz przypuszczał nawet, że język chiński kryje całą prawdę o rzeczach. Nie był tu zresztą odosobniony, podobną opinię wyraził znacznie wcześniej Francis Bacon, który twierdził, że ideogramy tego języka są to "Characteres real, which express neither letters nor words in gross, but Things or Notions" 73 .

F. Bacon był jednym z pierwszych, który rozważał projekt budowy języka uniwersalnego i który według jego zamysłu byłby systemem ideograficznym. Pisał o tym w The Advancement of Learning (1605), a także w późniejszej rozprawie De Augumentis Scientiarum (1623). Choć Bacon dostrzegał pewne korzyści z urzeczywistnienia swego pomysłu - „any book written in characters of this kind can be read off by each nation in their own language", to trudnością samą w sobie byłoby opanowanie takiego języka, gdyż zawierałby „a vast multitude of characters; as many, I suppose, as radical words" 74 . Sama idea Bacona była jednak na tyle nośna, że pojawiły się liczne próby jej urzeczywistnienia. Wymienić tu można wspólny projekt Williama Bedella, biskupa Kilmore i Wielebnego Jonstona z 1633 r., projekt Hermana Hugo, Philipa Labbé i Edwarda Somerseta. W 1657 r. Cave Beck opublikował w Ipswich gramatykę i słownik takiego języka pt. The Universal Character, By which all the nations in the world may understand one another'c Conceptions, reading out of one Common writing their own Mother Tonques. Podobne prace wydane zostały przez J. J. Bechera we Frankfurcie w 1661 r. (Character, pro

73 F. Bacon, The Advancement of Learning, w: Philosophical Works, ed. J. M. Robertson, 1905, s. 121.

74 F. Bacon, De Augumentis Scientiarum, w: Philosophical Works, ed. J. M. Robertson, s. 522. 
notitia linguarum universali) i Athanasiusa Kirchera w Rzymie w 1663 r. (Polygraphia Nova et Universalis) ${ }^{75}$.

Trudności, na które wskazywał Bacon, zdawał się przezwyciężać program nakreślony przez Kartezjusza we wspomnianym już wcześniej liście do Mersenne'a. Sam Kartezjusz, choć przekonany o teoretycznej możliwości skonstruowania języka uniwersalnego, którego struktura odwzorowywałaby struktury myślenia, nigdy nie podjął się próby realizacji, uznając, że wpierw trzeba jednak odkryć "prawdziwą filozofię". Co więcej, mimo dostrzeżenia wartości poznawczej takiego języka, wyraził on zasadniczy sceptycyzm co do możliwości praktycznych ${ }^{76}$. Program kartezjański stał się wyzwaniem dla innych badaczy i jako jeden $\mathrm{z}$ pierwszych podjął je Mersenne, który wspomina o swoim projekcie w liście z 1636 lub 1637 r. ${ }^{77}$ Do idei kartezjańskiej nawiązuje projekt Lodowicka, przedstawiony w książce z 1647 r. pt. A Common Writing, whereby two, although not understanding on the other's language yet by the help theroeof may comunicate their minds one to another i udoskonalony w pracy z 1652 r. pt. The Groundwork, or foundation laid (or so intended) for the framing of a new perfect language and an universal or common writing. Uniwersalny język Lodowicka był systemem ideograficznym. Jedynym projektem opartym na fonogramach był system przedstawiony przez Sir Thomasa Urquharta w 1651 r. ${ }^{78}$

Na szczególną uwagę zasługuje idea języka uniwersalnego Setha Warda z 1654 r. W pracy Vindiciae Academiarum ${ }^{79}$ pisał: „ponieważ wszystkie rozprawy ustanawiane są $\mathrm{w}$ zdaniach, a te $\mathrm{w}$ słowach, słowa zaś oznaczają proste pojęcia lub są do nich sprowadzalne, wskazuje to, że jeżeli wykryje się wszystkie rodzaje prostych pojęć i przyporządkuje się im symbole, których, w porównaniu $z$ innymi, będzie wyjątkowo niewiele, a zatem zasady ich złożeń będą łatwo rozpoznawalne, tak więc najbardziej nawet złożone całostki będą natychmiast zrozumiałe i jeszcze będą przedstawiać bezpośrednio w widzialny sposób wszyst-

75 Zob. J. Cohen, On the Project of a Universal Character, "Mind”, Vol. LXIII, 1954, s. 54.

76 AT I, 81-82. Zob. J. Kopania, op. cit., s. 201.

77 AT I, 572.

78 Zob. J. Cohen, op. cit., s. 55.

79 S. Ward, Vindiciae Academiarum, 1654, s. 21. 
kie elementy złożenia i jako takie prowadzić będą w naturę rzeczy". Wprawdzie pomysł Warda nie dostąpił realizacji, ale przedstawiona przezeń idea mieści się $w$ ramach kartezjańskiego modelu języka, a co więcej, jest wyjątkowo zbieżna z późniejszymi projektami Leibniza. Leibniz nie powoływał się na pracę Warda, znał jednak inne angielskie projekty - opublikowaną w 1661 r. pracę George'a Dalgarno pt. Ars Signorum, vulgo Character Universalis et Lingua Philosophica oraz Essay towards a Real Character and a Philosophical Language (1668), której autorem był John Wilkins. Zdaniem Leibniza jednak, ani Dalgarno, ani Wilkins nie uchwycili wystarczająco doniosłości rzeczy i ich języki osiągnęły tylko jedno, są użyteczne jako narzędzie komunikacji - bo prawdziwa Characteristica realis, jakq sobie wyobrażam, powinna być zaliczona pomiędzy najprzydatniejsze narzędzia ludzkiego umystu, jako naturalnie posiadajaca nieprzezwyciężonq siłę $i$ do odkrywania $i$ do zachowywania $i$ do sqdzenia ${ }^{80}$. Trzeba wszak dodać, że projekty Dalgarno i Wilkinsa, chociaż nigdy nie były stosowane w praktyce, były pełnymi systemami językowymi, zaś plany Leibniza pozostały jedynie $\mathrm{w}$ sferze marzeń.

\section{Magiczny urok algorytmu}

Wprawdzie w poszukiwaniach doskonałego systemu reprezentacji myśli Leibniz miał licznych poprzedników, to jednak istnieje coś, co rozstrzyga o wyjątkowym charakterze leibnizjańskiej idei języka uniwersalnego. Kartezjusz, choć wskazał kierunek poszukiwań, to kwestionując użyteczność poznawczą jakiegokolwiek systemu językowego, odrzucił potrzebę ustanowienia języka uniwersalnego. Rozumiejąc znak w sposób czysto konwencjonalistyczny, głosił, że strona materialna znaku nie ma żadnego związku ze znaczeniem, co przeczyło użyteczności wyrażeń języka w operacjach myślowych. Oznaczało to, że myślenie, jako operacja na ideach, nie może być wsparte niczym materialnym. Kartezjańska metodologia odwoływała się zatem do bezpośredniego kon-

80 GP VII, 7: „[...] sed vera Characterstica realis, qualis a me concipitur, inter aptissima humanae Mentis instrumenta censeri deberet, invincibilem scilicet vim habitura et ad inveneniendum et ad retinendum et ad dijudicandum". Zob. M. Jurkowski, op. cit., s. 20-35. 
taktu umysłu z przedmiotem poznania. Zgodnie $\mathrm{z}$ nią bowiem umysł ujmuje rzecz nie poprzez słowo, które może się do niej odnieść, lecz poprzez jej ideę, jaką ma zawsze $\mathrm{w}$ sobie, a którą $\mathrm{w}$ danym momencie uświadamia ${ }^{81}$. Metodologia leibnizjańska wskazywała na nieodzowny charakter innego sposobu myślenia, w którym kontakt umysłu z obiektem poznania nie jest bezpośredni, ale odbywa się za pomocą znaków, jako tych narzędzi myślenia, które przedstawiają przypisany im obiekt. Znaki powinny spełniać jednak pewien warunek, zgodnie $\mathrm{z}$ leibnizjańską teorią reprezentacji powinny ów obiekt wyrażaćc82.

Ten pośredni sposób myślenia o rzeczach, w którym idea rzeczy nie ujawnia się jako przedmiot apercepcji, nazwany został przez Leibniza ślepym myśleniem (caeca cogitatio) ${ }^{83}$. Jest ono podobne do działań przeprowadzanych na dużych liczbach i Leibniz bardzo często odwoływał się do przykładów arytmetycznych obliczeń. Przekonanie, że w istocie każda operacja umysłowa polega na liczeniu, przejęte zostało wprawdzie od Hobbesa ${ }^{84}$, ale Leibniz nadał mu zupełnie nowy wymiar. Zakładając, że prowadzące do apercepcji myślenie jest analogiczne $\mathrm{z}$ pewnego rodzaju rachunkiem, doszedł do wniosku, że zastąpienie działań umysłu na każdym $\mathrm{z}$ jego etapów symboliką odwzorowującą te działania pozwoli odtworzyć cały proces poznawczy i ująć go w odpowiedni system regul. Istnieje bowiem, jak pisał, naturalny porządek idei wspólny aniołom i ludziom, i w ogóle wszystkim inteligencjom ${ }^{85}$. Cały zatem projekt budowy języka uniwersalnego był próbą odtworzenia owego naturalnego porządku.

Leibniz założył, że apercepcja, a więc myślenie prowadzące do idei, ma charakter algorytmiczny (tzn. rachunkowy). Nie wynika stąd, że każde myślenie na poziomie świadomości prowadzi do poznania, trudno też zgodzić się z poglądem, że wszelkie myślenie ma charakter algorytmiczny, choć niewątpliwie taki charakter mają, zdaniem Leib-

81 Zob. J. Kopania, Stanowisko Descartes'a w kwestii języka uniwersalnego, w: Znaczenie i prawda, red. J. Pelc, Warszawa 1994, s. 155.

82 Zob. G. W. Leibniz, Quid sit idea, GP VII, 263-264, Zob. też GP VII, 198-201.

83 Zob. m.in. Meditationes de cognitione, veritate et ideis, GP IV, 423.

84 Zob. De arte combinatoria, GP IV, 64, gdzie Leibniz pisze: „Hobbes merito posuit omne opus mentis nostrae esse computationem".

85 G. W. Leibniz, Nowe rozważania..., t. II, s. 11. 
niza, działania umysłu na poziomie nieświadomości. Języki etniczne, jako odwzorowujące porządek naszych odkryć, pozwalają odtworzyć wszelkie myśli, które pozostają $\mathrm{w}$ zgodzie $\mathrm{z}$ wewnętrznym porządkiem idei, ale odzwierciedlają też te działania umysłu, które prowadzą do błędnych sądów i przekonań ${ }^{86}$. Nie są to zatem systemy, które pozwalają odtworzyć rzeczywistą strukturę naszego poznania, choć niewątpliwie pozwalają wniknąc $w$ te obszary świadomości, które są werbalizowalne. Oczywiście, wydaje się, że jest możliwa próba przebudowy tych języków, tak by utworzony w jej wyniku system był izomorficzny $\mathrm{z}$ naturalnym porządkiem idei, ale wcześniej jednak należy znać ów porządek. Podjęty przez Leibniza wysiłek przebudowy języka łacińskiego wskazuje, że dostosowanie gotowego systemu językowego do jasnych nawet założeń o strukturze naszego poznania jest zadaniem jeśli niewykonalnym, to niesłychanie trudnym w praktycznej realizacji. Należy jednak pamiętać, że wizja języka doskonałego nie przesłoniła mu całkowicie użyteczności poznawczej języków już istniejących. Każdy język, zdaniem Leibniza, nadaje się do rejestrowania odkryć, każdy nawet najuboższy może wyrazić wszystko ${ }^{87}$. Jeśli jeszcze nie jesteśmy w stanie zbudować języka uniwersalnego, należy skupić się nad poznaniem i doskonaleniem własnego języka - języki etniczne, jako „najstarsze zabytki ludów" 88 , pozwalają "odtworzyć historię naszych odkryć" 89 , zaś postęp $\mathrm{w}$ nauce zależy od jasnego i precyzyjnego formułowania myśli ${ }^{90}$.

Założenie o istnieniu naturalnego porządku idei, który jest wewnętrznym systemem reprezentacji wewnątrzumysłowej, wynika z jednego $\mathrm{z}$ podstawowych założeń leibnizjańskiej metafizyki. Umysł, jako monada, zamknięty na wszelkie działania $\mathrm{z}$ zewnątrz, cały wszechświat odnajduje $w$ sobie. Naturalny porządek idei jest izomorficzny $z$ porządkiem wszechświata, porządek ten zaś jest konsekwencją działań

\footnotetext{
86 Zob. Rozprawa metafizyczna, XIV, w: Wyznanie wiary filozofa..., s. 114 oraz G. W. Leibniz, Podstawy formalizacji rozumowań, w: M. Gordon, Leibniz, s. 251: "Języki powszechnie używane obciążone są niezliczonymi wieloznacznościami i nie mogą spełniać zadań rachunku, w którym można by ujawnić błędy rozumowania na podstawie samej formy i struktury słów".

87 Analysis linguarum, C, 352, UG, $§ 59,87$.

88 G. W. Leibniz, Nowe rozważania..., t. II, s. 11.

89 Tamże, s. 11.

90 UG, § 4, GP IV, 138.
} 
Stwórcy, który wybierając najlepszy z możliwych światów, stworzył go zgodnie $\mathrm{z}$ wewnętrznym porządkiem własnych myśli, bo „Gdy Bóg rachuje i snuje myśli, świat się staje" ${ }^{91}$. Dla Leibniza, podobnie jak dla innych myślicieli, porządek świata jest porządkiem matematycznym, a sam Bóg jest matematykiem.

Wybitny współczesny matematyk Stanisław Ulam zauważa, że każdy formalizm, każdy algorytm ma w sobie pewien magiczny urok ${ }^{92}$. Leibniz zafascynowany pięknem matematyki, pozostawał niewątpliwie pod urokiem procedur algorytmicznych. Filum cogitationis, caeca cogitatio czy calculus to wyrażenia, które bezpośrednio odwołują się do idei algorytmu ${ }^{93}$.

$\mathrm{U}$ podstaw procedur algorytmicznych leży język zdefiniowany w czysto formalny sposób, to jest odwołujący się tylko do fizycznego kształtu wyrażeń i ich połączeń. Niewątpliwie taki właśnie język był ideałem, do którego dążył Leibniz. „Postęp sztuki inwencji rozumowej zależny jest w znacznej mierze od sztuki znakowania. [...] Gdyby utworzono albo jakiś ścisły język (nazwany przez niektórych Adamowym), albo przynajmniej pewnego rodzaju pismo prawdziwie filozoficzne, z pomocą którego pojęcia zostałyby sprowadzone do jakiegoś alfabetu myśli ludzkich, to by wszystko, do czego można dojść rozumem na podstawie danych, dało się uzyskać poprzez pewien swoisty rachunek w ten właśnie sposób, w jaki są rozwiązywane problemy arytmetyki lub geometrii" ${ }^{94}$.

Uzyskany w ten sposób system stałby się „pewnym zmysłowym i niejako mechanicznym przewodnikiem umysłu, zrozumiałym nawet dla najgłupszych. Jako, że podążanie za tekstem i myślenie będzie przebiegało stopniowo, oznacza to, że pisany tekst będzie wątkiem dla myśli" 95 .

Co więcej, pozwoliłoby to rozstrzygać o prawdzie w czysto mechaniczny sposób tak, że „prawda widzialna byłaby jak na obrazku,

\footnotetext{
91 Dialog o powiązaniu stów i rzeczy oraz o naturze prawdy, w: Wyznanie wiary filozofa..., s. 79.

92 S. Ulam, Przygody matematyka, Warszawa 1996, s. 305.

93 W. Marciszewski, R. Murawski, op. cit., s. 76.

94 GP VII, 198-199, przekład M. Gordon, w: Leibniz, s. 246.

95 GP VII, 14.
} 
jakby była wydrukowana przez maszynę. Stałoby się tak dzięki temu, że kryterium, które tworzyłoby prawdę, byłoby ustanowione w sposób mechaniczny czyniąc ją widzialną" 96 .

Historycy nauki wskazują, że leibnizjański projekt języka uniwersalnego antycypował zarówno program formalizacji języka matematyki ogłoszony w 1900 r. na II Kongresie Matematyki w Paryżu przez Davida Hilberta, jak i współczesny program Sztucznej Inteligencji, ze względu na przekonanie, że każdy twórczy przejaw ludzkiego myślenia jest $\mathrm{w}$ istocie rachunkiem ${ }^{97}$. Dzięki odpowiedniej symbolice można byłoby w każdej dziedzinie - o ile tylko podlega rozumowaniu - zrobić wszystko, co można zrobić $\mathrm{w}$ arytmetyce i geometrii.

Obiekt niedościgłych marzeń Leibniza, nowy język wyrażający wszystkie nasze myśli, wprawdzie trudny do zbudowania, ale latwy do nauki „z powodu swojego ogromnego pożytku i zdumiewającej łatwości zostanie wnet przyjęty przez wszystkich i cudownie się przyda porozumiewaniu wielu narodów, a to skłoni do jego przyjęcia. Ci, którzy będą pisać $\mathrm{w}$ tym języku, nie pomylą się $\mathrm{w}$ niczym, o ile unikną błędów rachunkowych, barbaryzmów, solecyzmów i innych omyłek $\mathrm{w}$ formach gramatycznych i budowie zdań. Język ten będzie miał ponadto cudowną właściwość: zamknie usta ignorantom. Będzie można bowiem mówić lub pisać $\mathrm{w}$ tym języku jedynie na te tematy, jakie się samemu rozumie. [...] Ponieważ rzeczywiście ci, którzy liczą, uczą się pisząc, a ci, którzy mówią, niejednokrotnie napotykają coś, o czym nie myśleli, lingua praecurrante mentem. Co będzie miało miejsce zwłaszcza w tym języku z powodu jego ścisłości. Tym bardziej, że znikną wszystkie ekwiwokacje i amfibolie, a wszystko, co będzie wypowiedziane zrozumiale, będzie powiedziane do rzeczy" 98 .

Naturalny porządek idei stanie się osiągalny dzięki symbolice, która odtwarza alfabet ludzkich myśli. Język odnajdzie w ten sposób utraconą przez wieki przezroczystość, pozwalając ujrzeć ideę poprzez jej znak. Będzie tym systemem, który łączy wszystkie języki etniczne, bo

\footnotetext{
96 GP VII, 10.

97 Zob. W. Marciszewski, Why Leibniz should not have believed in 'filum cogitationis', wyd. cyt., oraz tenże, From the mechanization of reasoning to a study of human intelligence, "Studies in Logic, Grammar and Rhetoric" XII/XIII, Białystok 1993/94, s. 5-60.

98 G. W. Leibniz, Przedmowa do nauki ogólnej, w: Wyznanie wiary filozofa..., s. 73-74.
} 
wszystkie powinny być redukowalne do tego wspólnego wzorca. Jeśli przyczyną istnienia wszystkich języków jest naturalny system idei, to mimo dzielących ich różnic stanowią one harmonijną całość, wyrażają bowiem tę samą rzeczywistość i odwołują się do tego samego wewnątrzumysłowego porządku myśli. Każdy język ujmuje tę rzeczywistość $\mathrm{z}$ innej perspektywy, podobnie jak każda monada postrzega świat $\mathrm{z}$ własnego punktu widzenia. Język doskonały to fizyczna reprezentacja postrzeżeń każdego myślącego umysłu. Jeśli tym, co różnicuje monady, jest perspektywa postrzeżeń, wynika stąd, że tej samej zasadzie podlega system te postrzeżenia ujmujący. W swym wyznaniu wiary w możliwość utworzenia uniwersalnej symboliki zadbał Leibniz o zgodność programu z zasadą indywidualizacji. Język ten bowiem stanowiłby miarę zaawansowania poznawczego jego użytkowników, którą byłby stopień znajomości i sprawności posługiwania się algorytmem. Prowadząc czy wręcz poprzedzając myśl, pozwoliłby uznawać jedynie to, co jawi się jako jasne i co jako takie jest wyrażalne, podobnie jak ma to miejsce $\mathrm{w}$ procesie apercepcji.

Poszukiwanie uniwersalnej symboliki jako najpotężniejszego narzędzia rozumu to wielka część europejskiej historii idei, którą stanowi nie tylko chęć wypracowania wspólnego narzędzia porozumiewania, ale potrzeba dotarcia do zasadniczych wspólnych sensów, które pozwoliłyby przezwyciężyć następstwa budowania wieży Babel. Pierwsze próby znalezienia języka doskonałego to sięgnięcie do hebrajskiej Biblii. Średniowiecze przyjęło sugerowane przez Pismo święte przekonanie o pierwotnym charakterze języka hebrajskiego, które przetrwało, jako ugruntowana teologicznie doktryna o pochodzeniu języka, aż do XVIII w. Dante Alighieri w traktacie De vulgari eloquentia pisał, że język hebrajski „zachował się po zamieszaniu babilońskim, by Jezus, przyszły zbawiciel świata, mógł mówić językiem łaski, a nie zamieszania" 99. Argumentów na rzecz hebrajskiej monogenezy dostarczała też żydowska mistyka. Według kabalistów tekst pisany Tory i Talmudu zawiera zaszyfrowany tekst wiecznej Tory, która istniała jeszcze przed Stworzeniem. Złamanie szyfru będzie więc kluczem do uzyskania ostatecz-

99 A. Heinz, Dzieje językoznawstwa w zarysie, Warszawa 1978, s. 81. 
nej mądrości. Leibniz był jednym z pierwszych, który zakwestionował prymat języka hebrajskiego jako pierwszego języka ludzkości, wskazując na prajęzyk, który czasami za Jakubem Boehme nazywał lingua adamica.

Poczucie pewności i piękna, którą niesie ze sobą symbolika matematyczna, stało się źródłem inspiracji dla licznych projektów języka uniwersalnego, powstających nie tylko $\mathrm{w}$ wieku XVII. W XX wieku o potrzebie takiego języka mówił L. Couturat ${ }^{100}$, a praktyczną realizację projektu przedstawił Peano, publikując w 1908 r. V tom Formulaire de Mathématique w wymyślonym przez siebie języku. Nie istnieje jednak powszechny język doskonały, w którym porozumiewamy się i w którym piszemy poezje, i który jednocześnie, jak chciał tego Leibniz, wiedzie nas za pomocą symboliki po ścieżce prawdy. Istnieje jednak matematyka, która jest pewnym zwięzłym sposobem sformalizowania racjonalnego myślenia $\mathrm{i}$ jest zadziwiająco skuteczna w wyjaśnianiu tajemnic świata fizycznego. Ten związek bardzo wyraźnie wskazał Leibniz, twierdząc, że u podstaw różnorodności zjawisk leżą zasady matematycznego porządku ${ }^{101}$.

100 L. Couturat, O języku międzynarodowym powszechnym, Lwów 1903.

101 Zob. P. Davies, Plan Stwórcy, przekład M. Krośniak, Kraków 1996, s. 165-167. 